\title{
LXXI. STUDIES IN CALCIUM METABOLISM. III. CALCIUM AND THE COAGULATION OF BLOOD.
}

\author{
BY CORBET PAGE STEWART AND \\ GEORGE HECTOR PERCIVAL (Grocers' Company's Research Scholar). \\ From the Departments of Medical Chemistry, Pharmacology and \\ Therapeutics, University of Edinburgh.
}

(Received January 31st, 1928.)

IT is commonly stated that calcium ions are necessary for the clotting of blood, a view which was apparently first put forward with definite evidence by Arthus and Pagès [1890] and later by Sabatani [1903]. It appears to depend firstly on the facts that blcod coagulation is prevented by the addition of oxalates which precipitate calcium, and by citrates which lead to the formation of an almost undissociated calcium salt, and secondly on the fact that blood in which coagulation has been prevented by addition of oxalate can be made to clot by the further addition of soluble calcium salt.

Recently Wadsworth, Maltaner and Maltaner [1927] have put forward a theory of blood coagulation according to which the process is initiated by the reaction, at a surface of contact, between ionised calcium salts and an active lipoid, with formation of an ionised calcium lipoid compound and acid. The chemical reasoning on which this hypothesis is based does not seem very convincing, but the paper is interesting as insisting on the necessity for calcium ions.

So far no direct evidence has been produced in support of the statement that calcium in the ionised state is an essential factor in blood coagulation. We found that the addition of sodium citrate to blood produced an effect, additional to the formation of an undissociated calcium salt-it broke down the undissociated non-diffusible calcium complexes of the blood. Since the amount of citrate added to the blood was vastly in excess of the amount required to combine with the whole of the calcium present, it seemed probable that almost all the calcium was existing as calcium citrate. Thus the question of the form of combination in which calcium aids coagulation was thrown completely open, since the citrate had combined with the ionised calcium, and probably with the non-ionic but diffusible calcium, as well as with that derived from the breakdown of the non-diffusible complexes.

In these circumstances it was thought desirable to investigate quantitatively the effect of addition of citrate to the blood on the various forms of combination of calcium and on the coagulability. 


\section{Experiments With CITRATED BLOOD.}

The amounts of sodium citrate recommended in text-books for the purpose of preventing blood clotting are undoubtedly greater than are really necessary, and we therefore first investigated the effect of varying amounts of sodium citrate on the coagulability of blood. Through the kindness of Mr Goffin we were afforded facilities for carrying out these and subsequent experiments at the municipal abattoir, using ox blood. As soon as the animal's throat was cut, a sample was collected, and 2 cc. were rapidly measured into each of a series of test-tubes containing varying amounts of solid sodium citrate. (Measured volumes of a standard sodium citrate solution were added to the tubes and evaporated to dryness.) The tubes were shaken at once to dissolve the citrate and obtain thorough mixing, and the coagulation time was measured from the time the sample was collected to the time when the tube could safely be inverted. A further sample from the same animal was set aside, and allowed to clot, the serum being taken for analysis. A series of serum samples was set up with sodium citrate added in concentrations equivalent to those used in the coagulation series, calculated on the assumption that the serum represented $60 \%$ of the whole blood. In these samples total calcium, diffusible and ionic calcium were determined. The total calcium and diffusible calcium were determined as described in the preceding papers of this series. For the determination of ionic calcium the method of Brinkman and Van Dam [1920] was employed. In this method, 1 cc. of the sample is added to each of a number of small tubes containing varying amounts of solid sodium oxalate. After standing for 1 hour, the tubes are examined, and note is made of that tube which is just clear, and that which is just turbid owing to precipitation of calcium oxalate. The solubility product of $\mathrm{Ca}{ }^{*}$ and $\mathrm{C}_{2} \mathrm{O}_{4}{ }^{\prime \prime}$ being known, it is then possible, since the concentration of $\mathrm{C}_{2} \mathrm{O}_{4}{ }^{\prime \prime}$ is known, to calculate the concentration of $\mathrm{Ca}^{*}$ with a degree of accuracy depending on the variations in the $\mathrm{C}_{2} \mathrm{O}_{4}$ " concentration of successive tubes. In practice the error is about $15 \%$. The differences observed, however, were so great as to be beyond even this experimental error. In dealing with serum it was often impossible to obtain any satisfactory result owing to the opalescence of the serum itself, but it was found that, as Brinkman and Van Dam state, those sera from which results could be obtained invariably gave values identical with those obtained from their clear ultra-filtrates. Throughout this work, therefore, the serum filtrate was employed in the estimation of ionic calcium. Table I shows the effect of sodium citrate on the coagulation time of ox blood, while Table II shows the effect of the salt, in corresponding concentrations, on the total, diffusible, and ionic calcium content of the sera from these same bloods. One case is shown graphically in Fig. 1. From these results several facts emerge. In the first place, it is evident that no precipitation of calcium takes place when sodium citrate is added in amounts just necessary to prevent coagulation, though considerably higher concentrations do produce such a precipitation. 
Table I. Effect of sodium citrate on the coagulation time of ox blood.

\begin{tabular}{|c|c|c|c|c|c|c|c|c|}
\hline \multicolumn{2}{|c|}{$\begin{array}{l}\text { Sodium citrate } \\
\text { g. per } 100 \mathrm{cc} .\end{array}$} & \multicolumn{7}{|c|}{ Coagulation time at $18^{\circ}$} \\
\hline Blood & Serum & 1 & 2 & 3 & 4 & 5 & 6 & 7 \\
\hline 0.00 & 0.00 & $5^{\prime} 13^{\prime \prime}$ & $8^{\prime} 45^{\prime \prime}$ & $5^{\prime} 46^{\prime \prime}$ & $5^{\prime} 5^{\prime \prime}$ & $9^{\prime} 0^{\prime \prime}$ & $8^{\prime} 45^{\prime \prime}$ & $3^{\prime} 50^{\prime \prime}$ \\
\hline 0.00 & 0.00 & 56 & 850 & $5 \mathbf{3 6}$ & 50 & 850 & 815 & 355 \\
\hline 0.01 & 0.017 & 420 & 730 & 430 & 510 & - & 815 & 415 \\
\hline 0.02 & 0.033 & 417 & - & 540 & - & 一 & - & - \\
\hline 0.025 & 0.042 & - & 一 & - & 530 & 720 & 835 & 355 \\
\hline 0.03 & 0.050 & 357 & 830 & - & - & - & - & - \\
\hline 0.05 & 0.083 & 45 & 820 & 655 & 645 & 90 & 635 & 425 \\
\hline $0 \cdot 10$ & $0 \cdot 17$ & - & - & - & 1320 & 130 & 1220 & 810 \\
\hline 0.125 & 0.21 & - & - & - & 2130 & 270 & 1315 & 120 \\
\hline $0 \cdot 15$ & $0 \cdot 25$ & 1522 & 110 & 1611 & 450 & 350 & 220 & 170 \\
\hline $0 \cdot 20$ & $0 \cdot 33$ & No coag. & No coag. & No coag. & No coag. & No coag. & No coag. & No coag. \\
\hline $0 \cdot 25$ & 0.42 & , & , & , & ", & ", & , & ", \\
\hline $0 \cdot 40$ & $0 \cdot 66$ & $"$ & $"$ & ", & ", & $"$ & , & " \\
\hline 0.50 & $0 \cdot 83$ & " & , & $\eta$ & " & " & ., & ", \\
\hline
\end{tabular}

Table II. Effect of sodium citrate on the total, diffusible, and ionic calcium of ox serum.

\begin{tabular}{|c|c|c|c|c|c|}
\hline \multirow{2}{*}{$\begin{array}{l}\text { Sodium } \\
\text { citrate } \\
\text { g. per } \\
100 \mathrm{cc} . \\
\text { serum }\end{array}$} & \multicolumn{5}{|c|}{$\begin{array}{l}\begin{array}{c}\text { Total calcium } \\
\text { mg. per } 100 \text { cc. serum }\end{array} \\
\end{array}$} \\
\hline & 3 & 4 & 5 & 6 & 7 \\
\hline 0.00 & $9 \cdot 50$ & $12 \cdot 00$ & $10 \cdot 05$ & $11 \cdot 30$ & $11 \cdot 30$ \\
\hline 0.01 & $9 \cdot 50$ & - & $10 \cdot 00$ & - & - \\
\hline 0.02 & - & - & - & - & \\
\hline 0.03 & - & $12 \cdot 00$ & - & - & - \\
\hline 0.04 & $\overline{9.50}$ & $=$ & 二 & - & - \\
\hline $\begin{array}{l}0.05 \\
0.06\end{array}$ & $\begin{array}{c}9 \cdot 50 \\
-\end{array}$ & $\overline{12.00}$ & 二 & 二 & $\bar{z}$ \\
\hline 0.07 & - & - & $10 \cdot 00$ & 二 & 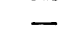 \\
\hline 0.08 & - & - & - & - & \\
\hline 0.09 & - & 12.00 & - & - & - \\
\hline 0.10 & - & - & - & - & - \\
\hline $\begin{array}{l}0.20 \\
0.30\end{array}$ & 二 & $\sqrt{12 \cdot 10}$ & 二 & $\bar{z}$ & $\bar{z}$ \\
\hline 0.40 & - & - & - & - & 二 \\
\hline & - & - & - & - & - \\
\hline $\begin{array}{l}0.80 \\
1.00\end{array}$ & $\overline{9 \cdot 60}$ & $12 \cdot 00$ & $10 \cdot 00$ & 二 & 二 \\
\hline 1.50 & $9 \cdot 40$ & 11.80 & $10 \cdot 00$ & 二 & - \\
\hline 2 & 8.70 & $10 \cdot 80$ & $10 \cdot 00$ & - & - \\
\hline & & & & & \\
\hline
\end{tabular}

\begin{tabular}{|c|c|c|c|c|c|c|c|c|c|}
\hline \multicolumn{5}{|c|}{$\begin{array}{l}\text { Diffusible calcium } \\
\text { mg. per } 100 \text { cc. serum }\end{array}$} & \multicolumn{5}{|c|}{$\begin{array}{l}\text { Ionic calcium } \\
\text { mg. per } 100 \text { cc. serum }\end{array}$} \\
\hline 3 & 4 & 5 & 6 & 7 & 3 & 4 & 5 & 6 & 7 \\
\hline 4.55 & $\begin{array}{l}5 \cdot 80 \\
6.00\end{array}$ & $\begin{array}{l}5 \cdot 30 \\
5 \cdot 20\end{array}$ & $5 \cdot 60$ & 6.45 & $\begin{array}{l}2.5 \\
1.5\end{array}$ & 2.5 & $2 \cdot 4$ & $2 \cdot 3$ & $2 \cdot 1$ \\
\hline $4 \cdot 60$ & 5.80 & $\begin{array}{l}0.20 \\
5 \cdot 25\end{array}$ & $\overline{5 \cdot 80}$ & 二 & at & $\stackrel{1.4}{-}$ & $1 \cdot 25$ & $\cdot 4$ & 二 \\
\hline & $5 \cdot 80$ & $5 \cdot 25$ & - & - & - & - & - & - & - \\
\hline $\begin{array}{l}.75 \\
.20\end{array}$ & $\begin{array}{l}6 \cdot 05 \\
6 \cdot 40\end{array}$ & $5 \cdot 25$ & $5 \cdot \overline{70}$ & $\overline{6 \cdot 25}$ & 0.7 & $\overline{0.43}$ & $0 . \overline{72}$ & $\overline{0.45}$ & $\overline{1.08}$ \\
\hline & 6.5 & $5 \cdot 25$ & 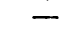 & - & - & - & - & - & - \\
\hline & & & - & - & 二 & $\bar{z}$ & $=$ & $\bar{z}$ & - \\
\hline & $\begin{array}{l}7.0 \\
7 \cdot 2\end{array}$ & $\begin{array}{l}5 \cdot 7 \\
6 \cdot 3\end{array}$ & Z & ב & 二 & 二 & I & 二 & - \\
\hline 80 & $7 \cdot 30$ & $7 \cdot 2$ & 8.10 & $7 \cdot 55$ & - & 0.36 & 0.27 & 0.27 & 0.36 \\
\hline & $9 \cdot 60$ & & & & - & 二 & $0 . \overline{24}$ & $0 . \overline{24}$ & $0 . \overline{27}$ \\
\hline & & & 10.90 & $10 \cdot 40$ & & & & & \\
\hline & 1( & & $11 \cdot 10$ & $11 \cdot 30$ & - & - & $>0.21$ & $>0.21$ & 0.21 \\
\hline & $\begin{array}{l}11.50 \\
11.50\end{array}$ & & - & - & $\overline{0.21}$ & $\overline{0.21}$ & $>\overline{0.21}$ & $>\overline{0.21}$ & $0 . \overline{21}$ \\
\hline & $11 \cdot 10$ & & - & - & & & & - & \\
\hline & & & - & - & & & 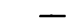 & 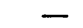 & \\
\hline & 80 & 5 & - & - & - & - & - & - & - \\
\hline
\end{tabular}

It is thus evident that, as is usually stated, sodium citrate does not owe its anti-coagulant power to any removal of calcium from the blood. Secondly, it may be noted that sodium citrate, even in very low concentrations, undoubtedly causes a serious diminution in the amount of ionic calcium in the bloodpresumably by the formation of calcium citrate which is commonly supposed to be almost undissociated, a fact which the authors have confirmed by measurements of the conductivity of calcium citrate solutions. It is obvious, however, that the diminution of calcium ions cannot be the cause of the loss of coagulability, for at a point when their concentration has been reduced to one-tenth of the original amount, the blood coagulates at the normal rate, and, in a number of cases, even more rapidly than when no citrate is present. Moreover, increased amounts of citrate have very little effect on the remaining 
ionic calcium. The third fact, which is shown in Tables I and II, and in Fig. I, is that with those concentrations of citrate which are without effect on the rate of coagulation (or slightly accelerate it) the diffusible calcium remains at the normal level, but coincident with the lengthening of the coagulation time there is an increase in the diffusible calcium, which becomes nearly equal to the total, precisely at that concentration of citrate which completely prevents coagulation from taking place. Regarded from another angle, it is seen that whereas the almost total loss of the ionised fraction of the calcium is without effect on the coagulation time, the loss of the non-diffusible calcium is accompanied by a lengthening of the coagulation time, and that loss of coagulability

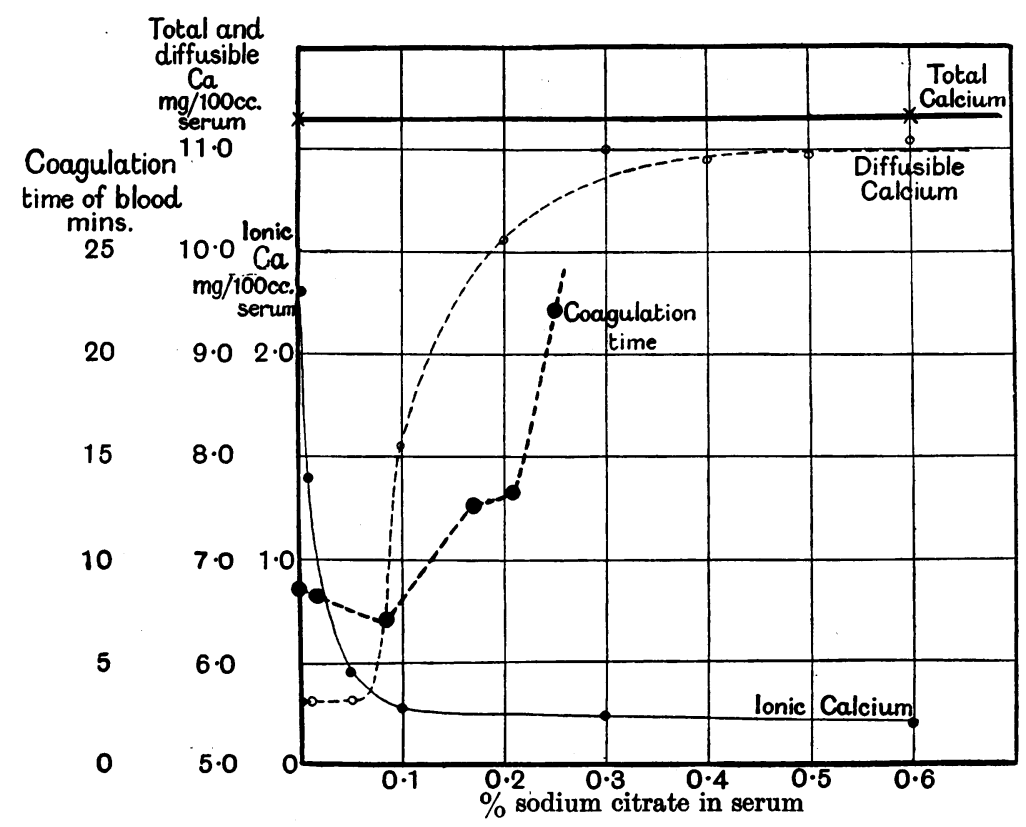

Fig. 1.

coincides with the reduction of this non-diffusible calcium to a very low level. The conclusion is inevitable-provided the validity of the data be grantedthat neither the ionic nor the simple undissociated compounds of calcium are necessary for coagulation, but that, as Vines [1921] has deduced from other considerations, some complex, undissociated calcium compound is.

In view of the proviso with which this conclusion is accompanied, it is necessary to point out in what way the experimental data may be held insufficient to justify the deductions drawn from them, and to give the reasons for which, in the authors' opinion, they are to be considered capable of supporting these deductions. The analytical figures themselves are of sufficient accuracy, for experience of the Kramer-Tisdall method extending over several years has convinced us of its reliability, and its capability, with careful work, of yielding results with an error of not more than $2 \%$. In the method used 
for determining the ionic calcium the error is much greater, but the changes are so gross, and occur with such unfailing regularity that no doubt remains of their essential reality. The same is true of the measurement of coagulation time; little reliance can be placed on small changes, but the method readily detects real changes of considerable magnitude. Criticism may, however, be directed to the fact that we have compared the effect of sodium citrate on the coagulation time of blood with the effect on the calcium content of the serum instead of the plasma. Of course, it was impossible to use plasma, which would have clotted long before collodion filtration was complete. The use of anticoagulants, obviously, was equally impossible and serum presented the only possibility. The objection to its use lies in the suggestions which have been made (e.g. by Vines) that in the distribution of calcium serum differs from plasma. It is true that, as the authors have themselves shown, serum contains less calcium than does true plasma, but in the same paper they have advanced arguments, derived from their own and others' work, in favour of the idea that calcium is similarly distributed in plasma and in serum. If this idea be accepted, the objection to the use of serum in the experiments here described falls to the ground. Even if it be rejected, it may still be argued that though the distribution may be quantitatively different in the two fluids, it must be qualitatively similar, in which case the data from serum analysis remain sufficient for their present purpose. For example, were the concentration of ionic calcium greater in plasma than in serum, it would be fair to suggest that the calcium ions disappear from serum with a concentration of citrate so low in comparison with that required to prevent coagulation, that there is ample "margin of safety." Similarly, if it be supposed that the concentration of nondiffusible calcium be higher in plasma than in serum, there is no doubt that citrate will equally in plasma, as in serum, produce a considerable diminution in this fraction. If it be agreed that the use of serum is justified, then the conclusions drawn from the experiments set out in Tables I and II are valid; if not, they are untenable, as also are those drawn from the further experiments yet to be detailed.

Reverting for a moment to the implications of the experiments with sodium citrate, a further point of some interest may be mentioned, although it will be dealt with more fully at a later stage. In several cases it was noticed that blood containing a small amount of citrate clotted more rapidly than normal blood. At these concentrations the amount of diffusible (and therefore of non-diffusible) calcium was normal; only the amount of ionic calcium had been altered. One may enquire whether calcium ions are not only unnecessary for blood coagulation, but actually have some inhibiting effect. This suggestion is made with great reserve for, as has already been mentioned, the method employed for the determination of the coagulation time is not one which can be relied upon in dealing with small changes. Moreover, the drop in the coagulation time was not observed in all cases, though there was never an increase with very low concentrations of citrate. Still, it is striking that in 
those cases where acceleration of clotting did occur, the return to normal coincided with the point at which the concentration of ionic calcium reached a low level whence it decreased only slowly with increased concentration of citrate. This coincidence is well shown in Fig. 1.

\section{EXPERIMENTS ON THE RECALCIFICATION OF CITRATED BLOOD.}

The addition of calcium chloride to citrated blood restores the power of coagulating, and if the conclusions reached in the first series of experiments are correct, recalcification should bring about an increase in the non-diffusible calcium of the blood. The case will be still further strengthened if coagulation takes place at a point where non-diffusible calcium is present in quantity while ionic calcium is still almost absent. In order to determine whether this was the case, ox blood was prevented from clotting by the addition of sodium citrate in amount corresponding to $0.42 \mathrm{~g}$. per $100 \mathrm{cc}$. plasma. Two hours after citration it reached the laboratory, and then $2 \mathrm{cc}$. were added to each of a series of test-tubes containing known amounts of dry calcium chloride. After thorough mixing, the tubes were allowed to stand and the coagulation times observed. A second sample of blood from the same animal was allowed to clot, the serum was mixed with sodium citrate $(0.42 \mathrm{~g}$. per $100 \mathrm{cc}$.), and allowed to stand for 2 hours. To a series of samples calcium chloride was added in the concentrations used for the citrated blood, and determinations of the total and diffusible calcium were made. As in all experiments described in this paper, the serum was centrifuged before being sampled for analysis.

\section{Table III. Effect of recalcification on the coagulability of citrated blood and on the calcium content of citrated serum.}

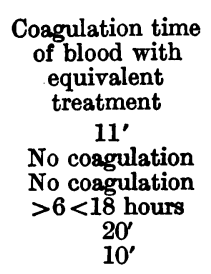

\begin{tabular}{|c|c|c|c|c|c|c|c|c|}
\hline \multicolumn{3}{|c|}{$\begin{array}{l}\text { Total calcium } \\
\text { mg. per } 100 \text { cc. } \\
\text { serum }\end{array}$} & \multicolumn{3}{|c|}{$\begin{array}{c}\begin{array}{c}\text { Diffusible } \\
\text { calcium }\end{array} \\
\text { mg. per } 100 \text { cc. } \\
\text { serum }\end{array}$} & \multicolumn{3}{|c|}{$\begin{array}{l}\text { Non-diffusible } \\
\text { calcium } \\
\text { mg. per } 100 \text { cc. } \\
\text { serum }\end{array}$} \\
\hline II & III & IV & II & III & IV & II & III & IV \\
\hline $\begin{array}{r}9 \cdot 0 \\
8 \cdot 6 \\
17 \cdot 0 \\
24 \cdot 9 \\
36 \cdot 6 \\
47 \cdot 0\end{array}$ & $\begin{array}{r}9 \cdot 75 \\
9 \cdot 10 \\
18 \cdot 25 \\
26 \cdot 30 \\
38 \cdot 20 \\
49 \cdot 30\end{array}$ & $\begin{array}{l}10 \cdot 8 \\
10 \cdot 1 \\
18 \cdot 4 \\
26 \cdot 6 \\
40 \cdot 0 \\
50 \cdot 0\end{array}$ & $\begin{array}{r}3.9 \\
8.1 \\
16 \cdot 2 \\
21 \cdot 9 \\
33 \cdot 3 \\
41 \cdot 4\end{array}$ & $\begin{array}{c}5 \cdot 70 \\
9 \cdot 10 \\
17 \cdot 0 \\
23 \cdot 85 \\
33 \cdot 60 \\
43 \cdot 2\end{array}$ & $\begin{array}{r}4 \cdot 6 \\
10 \cdot 0 \\
17 \cdot 9 \\
24 \cdot 3 \\
34 \cdot 8 \\
44 \cdot 1\end{array}$ & $\begin{array}{l}5.1 \\
0.5 \\
0.8 \\
3.0 \\
3.3 \\
5.6\end{array}$ & $\begin{array}{l}4 \cdot 05 \\
0 \cdot 00 \\
1 \cdot 25 \\
2 \cdot 45 \\
4 \cdot 60 \\
6 \cdot 10\end{array}$ & $\begin{array}{l}6 \cdot 2 \\
0 \cdot 1 \\
0 \cdot 5 \\
2 \cdot 3 \\
5 \cdot 2 \\
5 \cdot 9\end{array}$ \\
\hline
\end{tabular}

The results of experiments of this kind are shown in Table III. Addition of considerable quantities of calcium was necessary in order to restore coagulability. This, of course, was to be expected in view of the relatively huge amount of citrate added, which, assuming the salt used to be tri-sodium citrate, was chemically equivalent to $96 \mathrm{mg}$. of calcium. The table shows quite clearly, however, that with the return of coagulability there is a coincident increase in the amount of non-diffusible calcium, and that this amount approaches the normal level just as the coagulation time approaches the normal. Not only is this the case, however, but the concentration of calcium ions is also increased by recalcification, and, moreover, this increase, like that in the 
non-diffusible calcium, coincides with the return of coagulability. Considered alone, therefore, the recalcification experiments do not permit of any deduction as to the necessity of ionic calcium or of non-diffusible calcium. In the experiments on the direct citration of blood, however, there was so striking a reduction-amounting almost to a disappearance-of the calcium ions at concentrations of citrate which were totally without effect on the coagulation rate, that further evidence of the non-essential nature of calcium ions in blood clotting is hardly required. If then it be granted that the ions are not a factor in coagulation, the recalcification experiments do afford supporting evidence for the hypothesis that non-diffusible calcium is required.

\section{EXPERIMENTS WITH SODIUM FLUORIDE AS ANTI-COAGULANT.}

The methods employed in this and the following section need not be detailed since they were essentially the same as those used in the case of citrated blood. The results (Tables IV and V and Figs. 2 and 3) lead to the same conclusions as were reached when sodium citrate was the anti-coagulant. There is a rapid fall in the ionic calcium, which reaches a very low level at a fluoride concentration without any retarding action on coagulation. There is again a reduction in the non-diffusible calcium, noticeable only when the coagulation time begins to increase, and at a concentration of fluoride sufficient to prevent coagulation the non-diffusible calcium has been reduced to a small fraction of its original amount. The final result, though identical with that produced by citrate, is, however, reached by a different route. In the case of citrate,

Table IV. Effect of sodium fluoride on the coagulation time of ox blood.

Sodium fluoride

\begin{tabular}{ll}
\multicolumn{2}{c}{ g. per 100 cc. } \\
\hline Blood & Serum \\
0 & 0 \\
0 & 0 \\
0.09 & 0.15 \\
0.12 & 0.20 \\
0.15 & 0.25 \\
0.18 & 0.30 \\
0.22 & 0.37 \\
0.26 & 0.43 \\
0.30 & 0.50 \\
0.36 & 0.60
\end{tabular}

\begin{tabular}{|c|c|c|}
\hline \multicolumn{3}{|c|}{ Coagulation time at $18^{\circ}$} \\
\hline XVII & XXIII & $\mathbf{X L}$ \\
\hline $6^{\prime} 40^{\prime \prime}$ & $6^{\prime} 15^{\prime \prime}$ & $10^{\prime} 20^{\prime \prime}$ \\
\hline 645 & 610 & 1030 \\
\hline 640 & 620 & 1030 \\
\hline 245 & 555 & 950 \\
\hline 450 & 50 & 715 \\
\hline 540 & 635 & 1120 \\
\hline - & 850 & 180 \\
\hline 200 & - & 2240 \\
\hline 300 & 1430 & 300 \\
\hline No coag. & No corg. & No coag \\
\hline
\end{tabular}

Table V. Effect of sodium fluoride on the total, diffusible, and ionic calcium of ox blood.

\begin{tabular}{cccccc}
$\begin{array}{c}\text { Sodium fluoride } \\
\text { g. per } 100 \text { cc. }\end{array}$ & \multicolumn{4}{c}{$\begin{array}{c}\text { Total calcium } \\
\text { mg. per 100 cc. }\end{array}$} \\
$\overbrace{\text { Blood }}^{\text {Serum }}$ & XVII & XXII & XXIII & XL \\
0.00 & 0.00 & 9.60 & 10.60 & 10.50 & 10.4 \\
0.012 & 0.02 & 9.45 & - & - & - \\
0.03 & 0.05 & 9.25 & - & - & - \\
0.06 & 0.10 & 7.7 & - & - & 8.4 \\
0.12 & 0.20 & 6.9 & - & - & 6.7 \\
0.18 & 0.30 & 5.50 & - & - & 5.4 \\
0.24 & 0.40 & - & - & - & 4.8 \\
0.36 & 0.60 & 1.00 & 1.80 & 0.70 & 4.0
\end{tabular}

\begin{tabular}{|c|c|c|c|}
\hline \multicolumn{4}{|c|}{$\begin{array}{l}\text { Diffusible calcium } \\
\text { mg. per } 100 \mathrm{cc} .\end{array}$} \\
\hline XVII & XXII & XXIII & XL \\
\hline $\begin{array}{l}4 \cdot 80 \\
4 \cdot 25 \\
3 \cdot 65\end{array}$ & $\begin{array}{l}5 \cdot 60 \\
5 \cdot 17 \\
4 \cdot 15\end{array}$ & $\begin{array}{l}6 \cdot 30 \\
5 \cdot 60 \\
5 \cdot 05\end{array}$ & \\
\hline 1.30 & - & - & \\
\hline 0.70 & 0.66 & 0.60 & 9 \\
\hline $0 \cdot 15$ & 0.30 & 0.20 & 1. \\
\hline
\end{tabular}

\begin{tabular}{|c|c|c|c|}
\hline \multicolumn{4}{|c|}{$\begin{array}{l}\text { Ionic calcium } \\
\text { mg. per } 100 \text { cc. }\end{array}$} \\
\hline XVII & XXII & XXIII & $\overrightarrow{X L}$ \\
\hline $\begin{array}{l}2.88 \\
1.66 \\
0.54 \\
0.31 \\
0.21\end{array}$ & $\begin{array}{l}2 \cdot 4 \\
二 \\
=\end{array}$ & $\begin{array}{c}2 \cdot 50 \\
1 \cdot 40 \\
0.54 \\
0.36 \\
-\end{array}$ & $\begin{array}{l}2.50 \\
1.50 \\
0.54 \\
0.31 \\
\end{array}$ \\
\hline$>0.21$ & $>0.24$ & $>0.21$ & $>0.21$ \\
\hline$>0.21$ & $>0.21$ & 0.21 & $>0.21$ \\
\hline
\end{tabular}




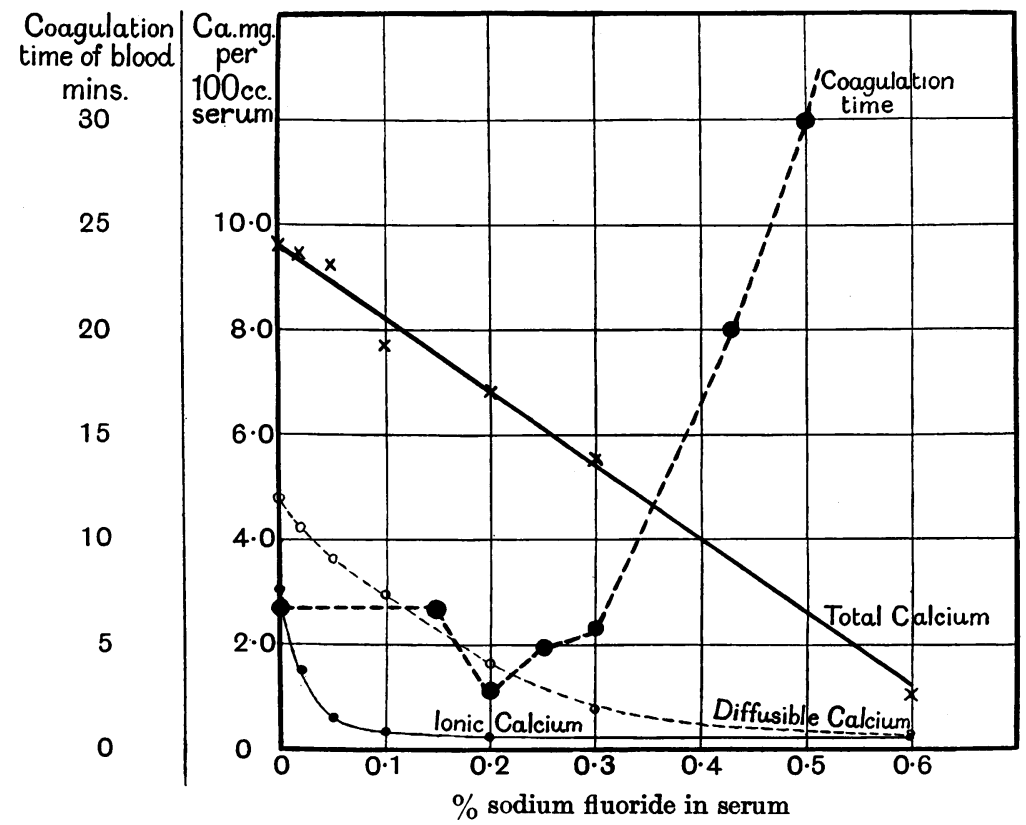

In all figures:

Fig. 2.
- - - Coagulation time.
०- - - o Diffusible calcium.
$\times \longrightarrow$ Total calcium.

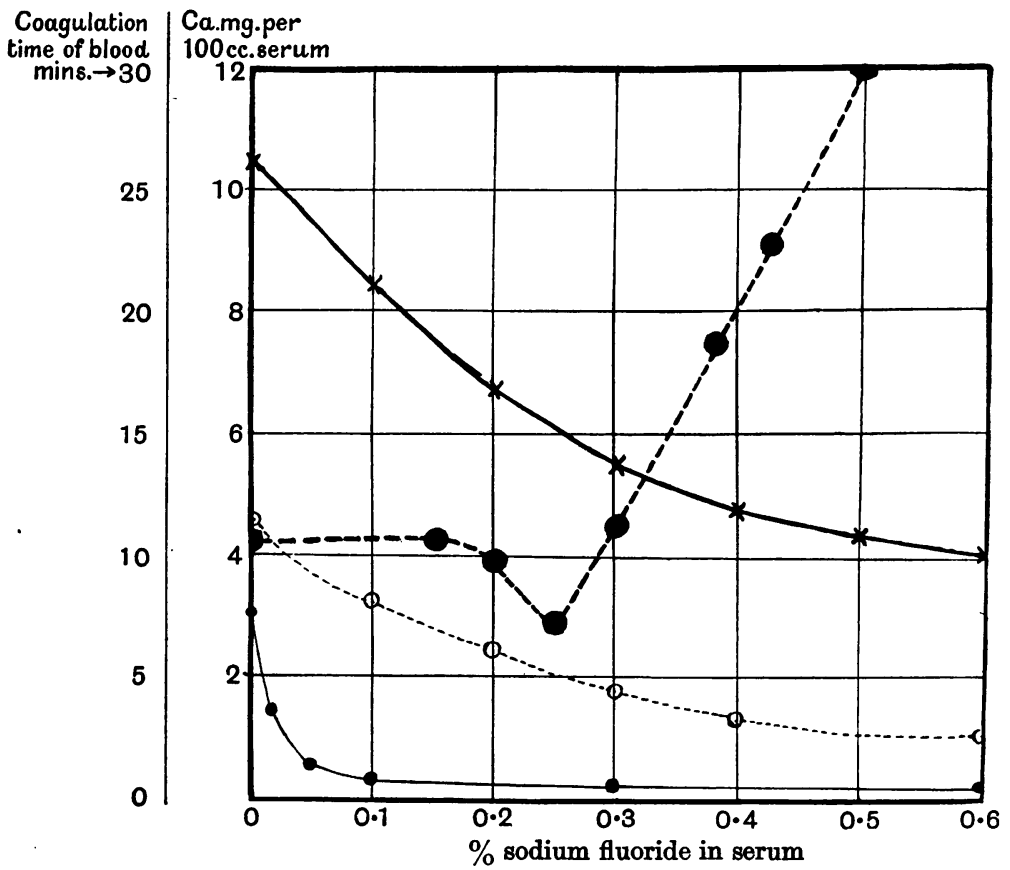

Fig. 3. 
almost the whole of the calcium formed some diffusible but almost un-ionised compound, presumably calcium citrate; in the case of fluoride, calcium is precipitated, and with low concentrations of fluoride, diffusible calcium is preferentially precipitated.

Addition of fluoride, like addition of citrate, to blood produces that curious phenomenon, an acceleration of clotting in presence of low concentrations of the anti-coagulant. Again the decrease in coagulation time coincides with the removal of the greater part of the calcium ions, and its return to normal with the appearance of the second effect of the salt-the decrease in the nondiffusible calcium. When, however, the analytical results were considered in further detail, it was noticed, in those first treated, that throughout the range of fluoride concentrations producing this improved coagulability there was actually a slight increase in the non-diffusible calcium. This is shown in Fig. 2 (Serum XXII), where the diffusible calcium values lie very well on a curve convex with respect to the straight line representing the corresponding values for the total calcium. This result, however, appears to be entirely fortuitous, for though it has been found in many cases, in others, almost equally numerous, the two curves, as in Fig. 3, are almost parallel, though slightly converging, from the start. Since, even in these cases, the blood showed the usual decrease in the coagulation time, there can be no causative relation between the coagulability and the increase in the non-diffusible calcium. It is difficult to explain the latter satisfactorily, though one may perhaps suggest an adsorption of calcium fluoride. In attempting to explain the more rapid clotting in presence of small amounts of fluoride, one is thus driven, as in the case of citrate, to suggest an actual inhibitory effect due to the calcium ions. The only alternative seems to be a slight alteration in $p_{\mathrm{H}}$ due to the presence of the anticoagulant. This possibility has not been considered experimentally, but it seems hardly likely, at any rate, that the two substances sodium citrate and sodium fluoride would alter the $p_{\mathrm{H}}$ in the same direction.

\section{EXPERIMENTS WITH SODIUM CHLORIDE AS ANTI-COAGULANT.}

Sodium chloride prevented blood coagulation at a concentration of $1.8 \mathrm{~g}$. per $100 \mathrm{cc}$. With the serum concentration corresponding to this, the nondiffusible calcium was again markedly reduced (though not to the extent observed in the case of citrate) by an increase in the amount of diffusible calcium (Table VI and Fig. 4). Once more there was a decrease in the coagulation time with low concentrations of anti-coagulant, and an early decrease in the concentration of calcium ions. The disappearance of ionic calcium was, however, slight when compared with that in the previous series of experiments, and indeed over $50 \%$ of the original concentration remained in sera corresponding to uncoagulable blood. Generally, the picture is very similar to that seen in the case of citrate, but is less strongly marked. From it alone no definite deductions could be drawn, but taken in conjunction with the other series, it affords confirmatory evidence of the necessity, in blood coagulation, of non-diffusible calcium. 
Table VI. Effect of sodium chloride on the coagulation time of ox blood and on the total, diffusible and ionic calcium of the serum.

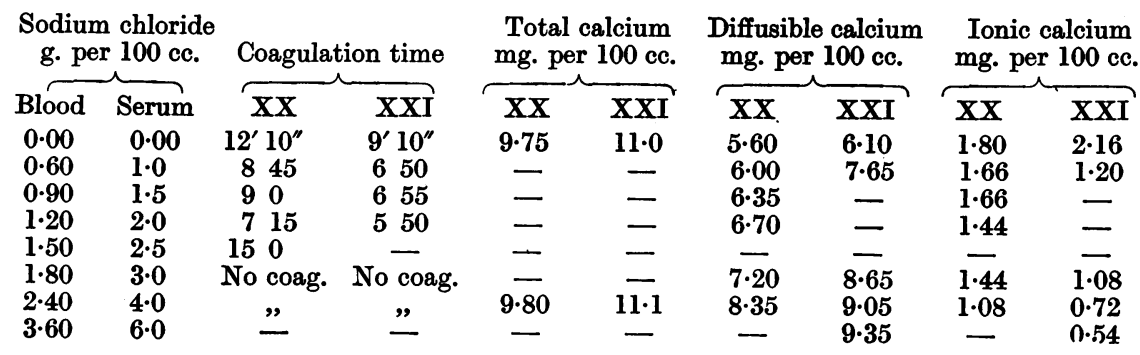

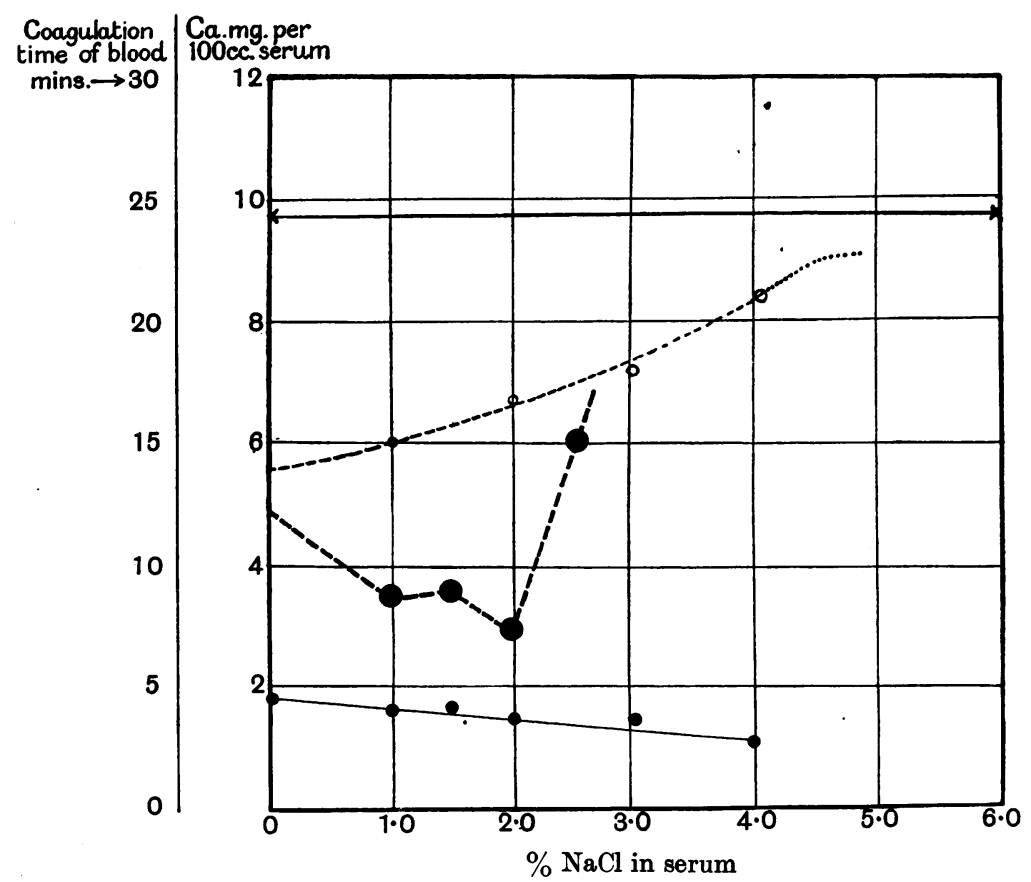

Fig. 4.

\section{EXPERIMENTS WITH SODIUM OXALATE AS ANTI-COAGULANT.}

In the experiments so far recorded, one factor was ignored; the time required for an equilibrium to be reached after the addition of the salt to blood or serum. Whether or not this omission is serious depends on the rate at which the equilibrium is adjusted in response to the addition of anti-coagulant. The essential action of the anti-coagulant takes place within some 5 or 10 minutes, the normal time of coagulation; the time required for filtration of serum is 2 hours. It has been tacitly assumed that the analyses made after the lapse of this preliminary filtration period give figures which represent the position in the serum 5 minutes after the addition of the anti-coagulant. It must be admitted that the neglect to take this factor into account was an oversight, 
but there is some evidence that in the cases so far considered it is not of great importance. Thus, in the experiments on aerated plasma described in the previous paper it was found that precipitation of calcium occurred within 6 minutes of the addition of sodium citrate, and was not appreciably greater after a lapse of 2 hours. The precipitation of calcium by fluoride also appeared to be rapid since samples of serum centrifuged $\frac{1}{2}$ hour and 2 hours after the addition of sodium fluoride were found to have identical calcium contents. In any case, so long as the changes proceed at a moderate rate, the effect of making the determinations after 2 hours (as the available methods render necessary) can only be to exaggerate somewhat the quantitative action of the anti-coagulant. Hence the omission of the time factor does not invalidate the conclusions drawn from these experiments.

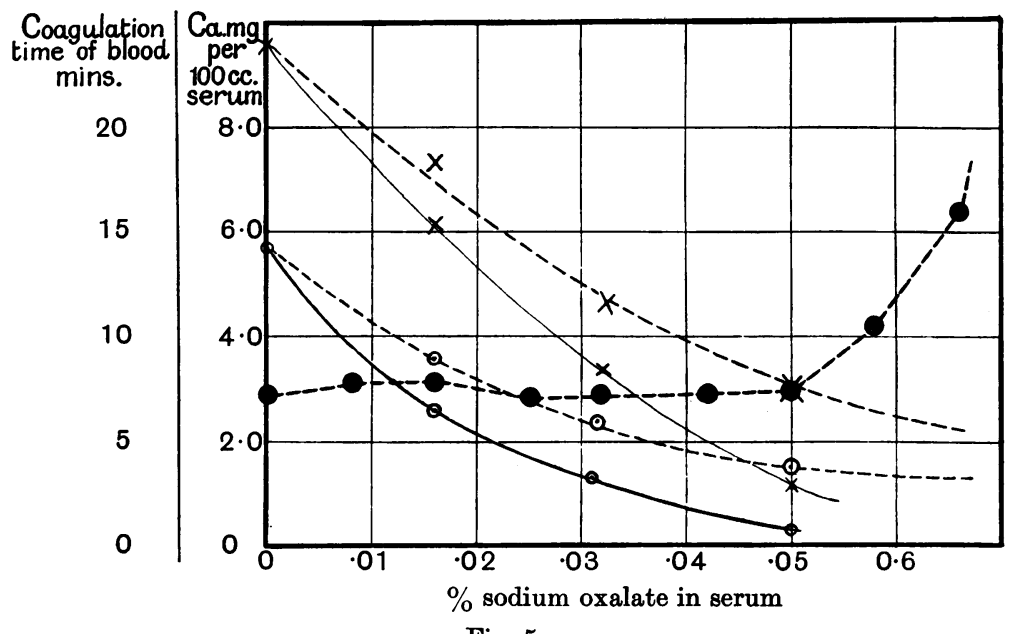

Fig. 5.

In dealing with sodium oxalate, however, an attempt has been made to take the time factor into account. To this end the filtration of the serum was, as usual, commenced immediately after addition of sodium oxalate. Enough filtrate for analysis was obtained after 2 hours. The filtrate was centrifuged before withdrawal of the sample. Now the precipitation of calcium by oxalate is not complete in 2 hours, but experiments reported in the preceding paper of this series showed that with small quantities of oxalate the amount of calcium precipitated in 120 minutes was approximately 1.33 times the amount precipitated in 10 minutes. Hence it was possible to calculate, approximately, the amount of diffusible calcium present in the serum 10 minutes after the addition of the anti-coagulant. For the determination of total calcium, the serum was centrifuged for 2 minutes, commencing 8 minutes after the addition of the oxalate so that samples for analysis were obtained after the re-adjustment of the equilibrium had been in progress for 10 minutes. To test the correctness of this method of calculation, the serum remaining after withdrawal of samples for analysis was again centrifuged after the lapse of 1 hour, 
and a second series of samples was withdrawn for analysis. The amount of calcium precipitated in 1 hour is approximately 1.25 times the amount precipitated in 10 minutes, and calculation on this basis from the results obtained in the second series gave values in good agreement with those obtained by direct determination. For routine purposes, therefore, the whole serum was centrifuged 1 hour after the addition of the sodium oxalate and the results for a 10 minutes' period were then calculated in the same way as those for the diffusible calcium. Determination of ionic calcium was not attempted. The results are shown graphically in Fig. 5, where the continuous lines represent the actual figures obtained by analysis, and the dotted lines the figures obtained by calculation representing approximately the position 10 minutes after the addition of the sodium oxalate. As in the series of experiments previously described, there is a progressive decrease in the concentration of non-diffusible calcium, and it is only when this concentration becomes very small that coagulation is delayed and finally prevented. The experiments thus lead to exactly the same conclusions as do those with other salts with an anticoagulant action.

\section{SUMMARY.}

From experiments on the effect of sodium citrate, sodium fluoride, sodium chloride, and sodium oxalate on the coagulation time of ox blood and on the concentration of calcium, diffusible calcium, and ionic calcium of the corresponding serum, it is concluded that some complex calcium compound, incapable of filtration through a collodion membrane, is essential for the coagulation of blood. Calcium ions are not necessary, and it is tentatively suggested that they may actually have an inhibitory effect.

One of us (C.P.S.) is in receipt of a personal grant from the Medical Research Council. The expenses of the work were partly defrayed by a grant from the Moray Research Fund of this University.

\section{REFERENCES.}

Arthus and Pagès (1890). Quoted by Howell. Textbook of physiology. 8th ed. 1922. p. 456.

Brinkman and Van Dam (1920). Proc. K. Akad. Wetensch. Amsterdam, 22, 762.

Sabatani (1903). Arch. ital. Biol. 39, 333.

Vines (1921). J. Physiol. 55, 86.

Wadsworth, Maltaner and Maltaner (1927). Amer. J. Physiol. 80, 502. 